\title{
Permafrost (Cryolithozone) of the Russian Arctic Shelf
}

\author{
N.A. Shpolyanskaya \\ Moscow, Lomonosov Moscow State University, 119992 Moscow, Russia \\ *Corresponding author nellashpol@yandex.ru
}

Copyright (C) 2014 Horizon Research Publishing All rights reserved.

\begin{abstract}
The problem of age nonuniformity of the permafrost of the Russian Arctic shelf is considered in this paper. It is assumed that recent permafrost exists on the present-day shelf in addition to the cryolithozone, which was formed under subaerial conditions during shelf draining in the Late Pleistocene, was flooded during the subsequent transgression, and exists as a relic zone. It is considered whether permafrost can be formed immediately under submarine conditions. The mechanism of bottom soil freezing and ice formation, based on constant natural transformations in seabed sediments, is proposed. The proposed mechanism is confirmed by analyzing certain sections of the bottom sediments of shelf and of the Pleistocene marine plains (ancient shelves) composed of dislocated sequences with massive ice beds. On the basis of a ground massive ice genetic analysis different geological development as well as different transgressive and regressive regime of the Russian Arctic western and eastern sectors was revealed. The glacial cover limited distribution in the Russian North and its absence on the Russian Arctic and Subarctic plains to the East of the Kanin Peninsula were noted.
\end{abstract}

Keywords Massive Ground Ice; Sheet Ice; Polygonal Wedge Ice; Subsea Permafrost Zone; Quaternary History of the Russian Arctic Permafrost

\section{Introduction}

Permafrost (cryolithozone) is one of the elements of the Arctic zone natural conditions, which substantially complicates shelf development. It is known that the present-day Arctic shelf bottom is mostly composed of frozen rocks often of high ice content. Most researchers assume that the cryolithozone within the shelf is relic, was formed during a deep Late Valdai (Sartan) sea regression, and was subsequently flooded during the Late Pleistocene Holocene transgression. During sea regression, the shelf was drained to a bottom contour of 100-120 $\mathrm{m}[1,2]$, and permafrost of a large thickness was formed within the shelf. At present, the cryolithozone is traced in the Arctic Seas as a relic permafrost $[3,4]$ with a thickness of up to $500 \mathrm{~m}$ and more, for example, in the Laptev and East Siberian Seas [5, 6]. However the main feature of the ground ice distribution is a sharp distinction between Western and Eastern sectors of the Arctic [7]. In the Eastern sector polygonal wedge ice is spread almost solely, while in the Western sector the massive ice bed dominates. Genetically, these are essentially different formations, and it is the fact that points to the different development history of the two parts of the Arctic.

\section{Materials and Discussion}

\subsection{Western Sector of the Arctic Shelf Seas [8] (Fig. 1)}

Bottom permafrost was found at depths from 0 to $230 \mathrm{~m}$ [9, 10]. Permafrost table can lie at the approximate depth of 20-40 m under the sea floor or rise to the bottom surface. Permafrost base sinks to $100 \mathrm{~m}$ and lower. In bottom permafrost sediments sections there is a large amount of ice, sometimes up to $100 \%$ (Fig. 2). Many authors consider the permafrost to be relict here. However, the very fact of permafrost occurrence at depths from 0 to $230 \mathrm{~m}$ indicates its heterogeneous nature. Even if we accept the idea of the Late Valdai sea regression to the isobath of 100-120 m which led to the shelf soils freezing in subaerial conditions, there are still vast areas with the sea depth from 100-120 to $230 \mathrm{~m}$ where permafrost must have formed directly in subsea conditions. Let as recall that there are opinions of the sea level drop to only $-30 \div-50 \mathrm{~m}[11]$.

It is known that icy bottom sediments are formed, e.g., in the southeaster Barents Sea, southwestern Kara Sea [9, 12-14], and in the eastern Laptev Sea, where frozen marine syngenetic sediments have been encountered $[15,16]$. This data indicate that the cryolithozone is nonuniform within the Arctic shelf. This zone includes both relic and recent, newly formed, permafrost.

Several circumstances cause us to reveal an age nonuniformity of the permafrost within the shelf for many reasons. First, many fundamental problems of origination of thick Pleistocene sediments and Quaternary history of the Russian Arctic regions can be solved by using the cryolithological methods: certain issues of the Arctic shelf paleogeography can be elucidated by admitting that permafrost can be formed immediately on seabed. 


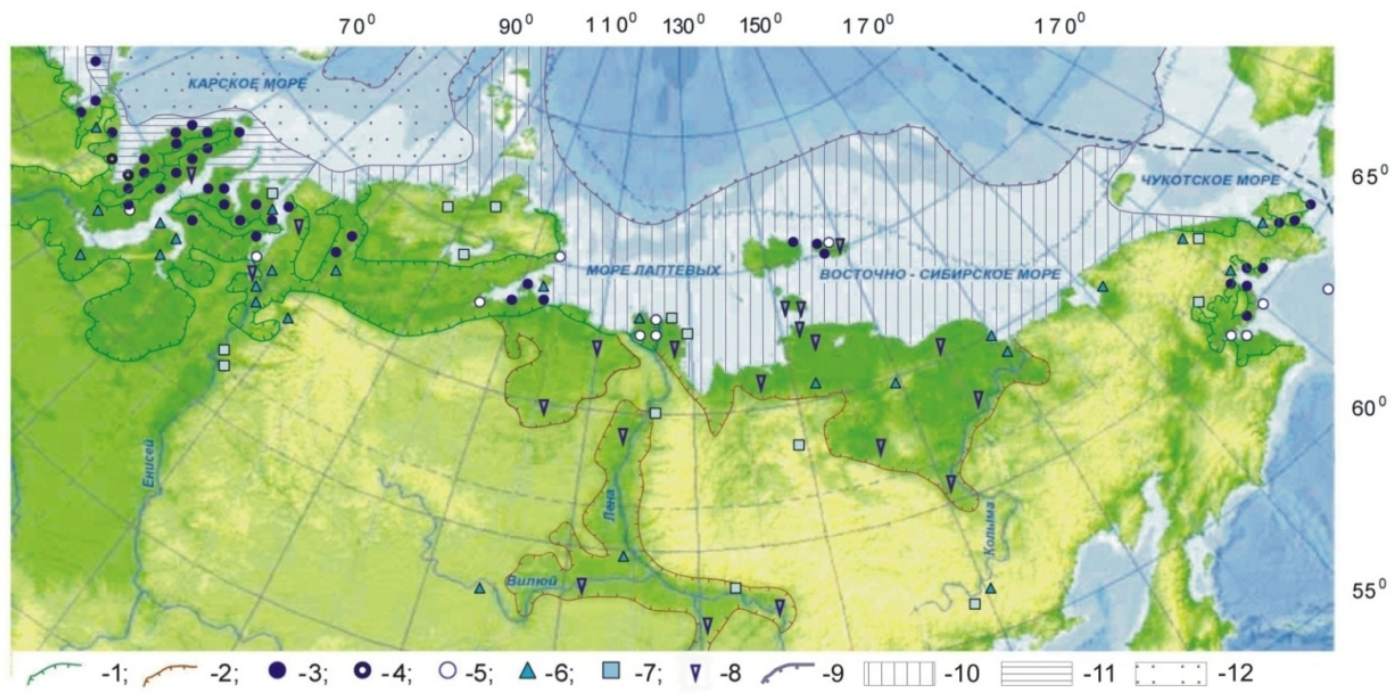

Prepared by I.D. Streletskaya and N.A. Shpolyanskaya, the shelf is given according to V.A. Solovev and S.I. Rokos with additions by N.A. Shpolyanskaya. 1 - Late Pleistocene marine plain boundaries; 2- Pleistocene lacustrine-alluvial plains boundaries; 3-8 - ground ice thick beds: 3 - subsea genesis, 4 - mixed genesis, 5 - coastal-marine genesis, 6 - injected genesis, 7 - buried (primarily surface); 8 - polygonal wedge ice; 9 - shelf outer boundary; 10-12 - shelf cryolithozone: 10 - relict permafrost with a temperature of $0 \ldots-2^{\circ} \mathrm{C}$, up to $200 \mathrm{~m}$ or over thick, 11 - modern permafrost with a temperature of $0 \ldots-1.5^{\circ} \mathrm{C}$, $80-100 \mathrm{~m}$ thick, 12 - cooled soils with newly formated permafrost islands with a temperature of $0 \ldots-1.5^{\circ} \mathrm{C}, 80-100 \mathrm{~m}$ thick

Figure 1. Map of ground ice.

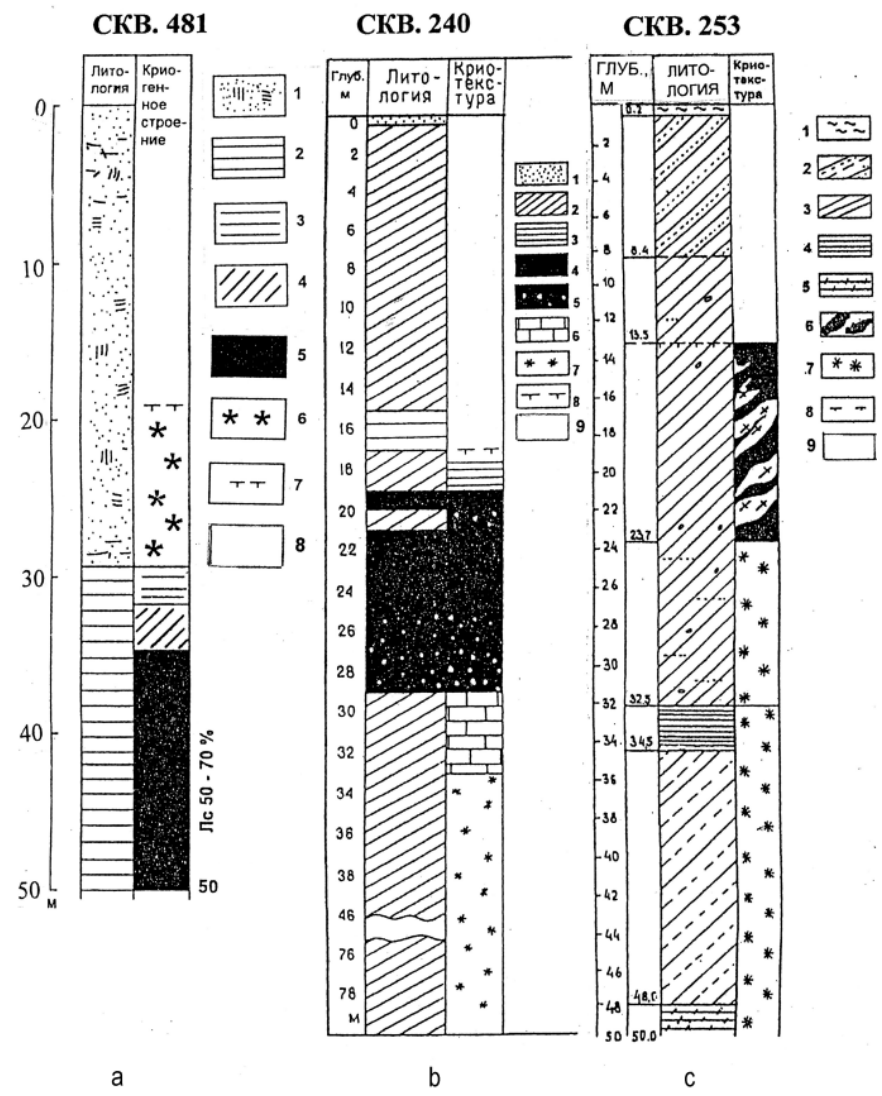

a - drill 481 in the Kara Strait area (sea depth is $65 \mathrm{~m}$ ). 1 - sand with organic material inclusion; 2 - clay. 3 - 6 cryogenic structure: 3 - horizontally layered; 4 - dislocated subvertical large-schlieren; 5 -ataxitic (sheet ice); 6 - massive. 7 - permafrost table. 8 - negative-temperature precipitations.

b - drill 240 in the Baydaratskaya Bay (sea depth is 13-14 m). 1 - sand; 2 - clayey silty loam; 3 - clay; 4 - 7 cryogenic structure: 4 - sheet ice; 5 - ataxitic; 6 - reticulate ; 7 - massive. 8 - permafrost table. 9 - negative-temperature precipitations.

c - drill 253 in the Kara Sea on the Rusanovskaya Field (sea depth is $130 \mathrm{~m}$ ). 1 - silt; 2 -rhythmical interbedding of sand, sandy silty loam and clayey silty loam; 3 - claye silty loam; 4 - clay; 5 - argillite-like firm clay; 6 - sheet ice; 7 - massive cryogenic structure. 8 - permafrost table. 9 - negative-temperature precipitations.

Figure 2. Bottom sediments section on the Barents-Kara Shelf (Melnikov and Spesivtsev 1995). 
Second, by admitting the possibility of formation of initially submarine cryolithozone, we can explain the origin of certain types of massive ice, which is encountered in sediments of the Pleistocene marine plains (i.e., ancient shelves), and to reveal the origin of brines at negative temperature (cryopegs) frequently observed in the Arctic regions. Data of the genetic relation between cryopegs, massive ice beds, and marine host rocks are published [17]. Third, the directional evolution of the shelf cryolithozone affects the development of the shelf offshore and near-shore parts and, therefore, makes it possible to predict the dynamics of Arctic coasts and assess the degree of their stability. Fourth, the directional development of the shelf permafrost (degradation and growth of relic and recent submarine permafrost, respectively) is responsible for the geoenvironmental conditions within the shelf and, thereby, for the conditions of shelf development.

The paper proposes the conceptual author's viewpoint that the Arctic sea bottom sediments can freeze and the permafrost can now be formed within the Arctic shelf. The mechanism of permafrost formation under submarine conditions is proposed, and certain criteria for age division of the shelf cryolithozone are revealed.

\subsection{Analysis of Conditions for Syngenetic Freezing of Bottom Sediments}

The possibility of bottom sediment freezing depends on the relationship between the pore water salinity and temperature of sediments $[18,8]$. In this respect, the following data are available.

\section{Temperature}

The average annual temperature of the upper horizons of bottom sediments (Ts) is as a rule equal to the temperature of the bottom water layer, the regularities in the spatial variations of which have been adequately studied. The temperature evidently depends on the Arctic sea depth [19]. Negative temperature is the lowest at a zero sea level. With increasing sea depth to $2 \mathrm{~m}$, temperature increases and reaches $0^{\circ} \mathrm{C}$ at the fast ice boundary of the maximal thickness, equal to the sea depth. At a further increase in sea depth, temperature continues increasing, becomes positive, and reaches its maximum $\left(2.8^{\circ} \mathrm{C}\right)$ at depths of $2-3 \mathrm{~m}$, where ice floats. This is caused by a considerable summer heating of shoals. If sea depth continues increasing, temperature starts decreasing again and crosses $0^{\circ} \mathrm{C}$ once more (becomes equal to $-0.2^{\circ} \mathrm{C}$ ) at a depth of $7-8 \mathrm{~m}$. Beginning from a sea depth of $16-18 \mathrm{~m}$, bottom water has a stable negative temperature. The temperature decreases to a depth of 30-35 m, where it reaches the minimal values $\left(-1.6 \div-1.8^{\circ} \mathrm{C}\right)$. Homothermy is often observed at depths of 35-40 through $250 \mathrm{~m}$; i.e., the bottom layer temperature remains unchanged at these depths where annual temperature variations are absent. Below these depths, temperature gradually increases to $0.8^{\circ} \mathrm{C}$ at a depth of $500 \mathrm{~m}$. A similar pattern for the Kara Sea is presented in $[20,21]$. The described temperature distribution in the bottom water layer indicates that stable negative temperatures are formed at rather large depths of about $40-250 \mathrm{~m}$ in the Arctic seas.

\section{Salinity (S)}

The published data on the salt content of bottom sediments make it possible to draw rather definite conclusions on the mineralization character. The salt distribution over the section is nonmonotonic. The mineralization in the surface layer of bottom sediments is usually higher than the salt content of bottom water [19, 22-25]. Pore solution salinity decreases from bottom surface downward. O.V. Shishkina [25] established both these effects when she studied the variations in the chlorine content of sludge water in different seas. She observed that the chlorine content of the upper layer of sediments was higher than that of the bottom water by $0.6-1.1 \%$ on the southwestern African shelf, by 0.7 $2.3 \%$ on the Peruvian offshore slope and shelf, by $0.5-$ $0.7 \%$ on the eastern coast of California, and by $2.12 \%$ on the Sea of Okhotsk shelf. The chlorine content decreases with increasing depth in many regions: on the offshore slope of the South American continent in the Atlantic, at a large distance from the coast in the northeastern Atlantic at a sea depth of $3000 \mathrm{~m}$ (from 19.3\% in the surface layer to $15.1 \%$ at a depth of $4.3 \mathrm{~m}$ ), in the Black (from 12.5 in the surface layer to 9.5 at a depth of $4.5 \mathrm{~m}$ and to $4-6 \%$ at a depth of $8-10$ $\mathrm{m}$ ) and Baltic marginal continental seas, and near the coast of the open Norwegian Sea. The works I.A. Komarov and D.S. Lukovkin [26] and A.N. Khimenkov and A.V. Brushkov [27] also report that the pore water concentration in bottom sediments decreases down the section (Fig. 3).

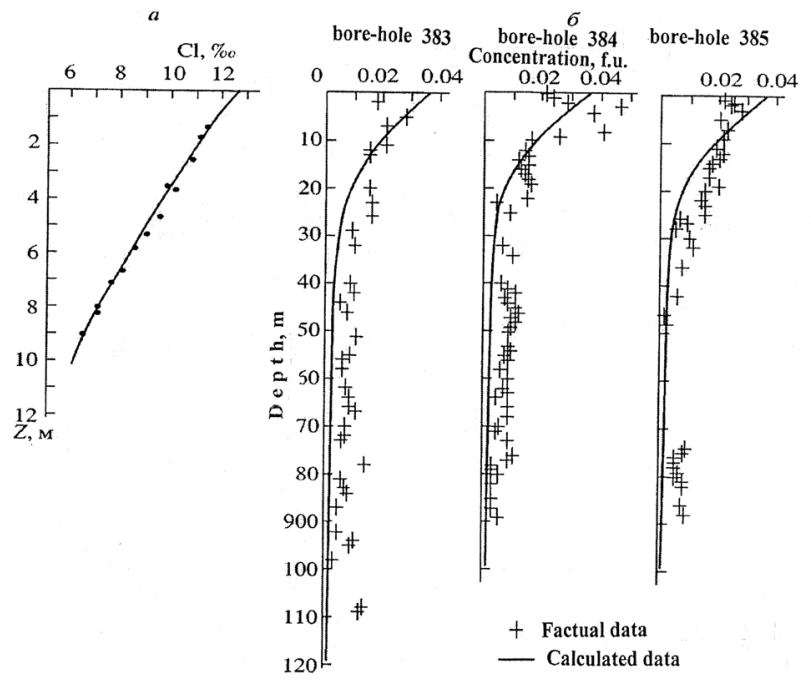

Figure 3. Vertical variations in pore solution salinity in bottom sediments: $a$ - Black Sea (Shishkina, 1972), $b$ - Barents Sea (Komarov and Lukovkin, 2001)

These data indicate that the directional variation in the bottom sediment salinity with changing depth is a universal phenomenon.

The cause of such a salt distribution has not yet been determined, although this cause is discussed in the literature. 
R. Horn [23] considered that ion exchange at the «seabed seawater» interface can cause a decrease in the salt content. During such an exchange, positive absorption and, consequently, an increase in the ion concentration in a pore solution can be observed in some cases, and negative absorption and a decrease in the ion concentration can be observed in other cases, e.g., in montmorillonite, which is the known mineral component of marine sediments. However, R. Horn considers that this disagrees with the fact that the salinity in the upper layers of sludge water remains higher than the seawater salinity. R. Horn simultaneously presents viewpoints of other searchers, who assume that sediment salinity decreases with depth as a result of a sediment consolidation However, R. Horn presents results of the experiment indicating that pressure does not affect the composition of water in clay. Moreover, ion diffusion forces should have equalized any concentration gradients since bottom sediments become less compact toward their surface. R. Horn did not find a satisfactory explanation of the existent salinity distribution in marine sediments.

Several researchers, O.V. Shishkina [24], L.G. Pavlova [28] and others, assumed that a decrease in salinity with increasing depth reflects a certain earlier geological stage, when glaciers thawed and seawater became less saline since fresh thawed water was discharged into sea. However, it is difficult to agree with this assumption for the following reasons. First, salinity also decreases at low latitudes in open sea, where glacial water could hardly pronouncedly affect seawater mineralization. Second, fresh water is always less dense than saline water and usually float over the sea surface in the form of lenses. A fresh-water lens thickness of even the largest world rivers, such as Orinoco and Amazon, is not more than 10-15 m, although these rivers flow into the open sea over a distance of several hundred kilometers [29]. In the not very deep Gulf of $\mathrm{Ob}$, the fresh water of the Ob River is underlain by the heavier saline water of the Kara Sea [19]. This phenomenon follows from a comparison of the fresh and sea water densities. Thus, maximal fresh water $(\mathrm{S}=2 \%$ ) density at a temperature of $4^{\circ} \mathrm{C}$ is $1,00163 \mathrm{~g} / \mathrm{cm}^{3}$, whereas the seawater $(\mathrm{S}=35 \%)$ density at a temperature of $-1^{\circ} \mathrm{C}$ is $1,028126 \mathrm{~g} / \mathrm{cm}^{3}$ [30]. Therefore, seawater freshening in the epoch of deglaciation hardly affected bottom water and could not influence mineralization of bottom sediments. This could take place only in isolated cases in the near-shore shallow-water areas of the shelf. Third, diffusion, which would inevitably have originated during the concentration gradient formation after deglaciation, should have equalized salinity of sediments during geological epochs, no matter how slow this diffusion may be. A stable mineralization gradient should be maintained due to some permanent process.

It seems that the cause of the considered salinity distribution in bottom sediments can be revealed by using the laws of irreversible thermodynamics. The fact is that the analyzed medium (bottom sediments) is simultaneously characterized by gradients of concentration and temperature related to the heat flux within the Earth. In this case the process of thermal diffusion [31], which means that mass is transferred under the action of temperature gradient, proceeds in addition to the diffusion process. The flux of ions directed oppositely to temperature gradient originates in bottom sediments. This process is described by the formula

$$
I=-D^{\prime} \rho C(1-c) \operatorname{grad} T-\rho D \operatorname{grad} C
$$

where $I$ is the concentration flux, $D^{\prime}$ is the thermal diffusion coefficient, $\rho$ is the density of a medium, $C$ is the solution concentration, $T$ is the temperature, and $D$ is the diffusion coefficient.

The first term in the right-hand side of the equation describes the process of thermal diffusion, i.e. a salt flux caused by temperature gradient and directed oppositely to this gradient (from lower soil layers toward the soil surface). The second term in the right-hand side of the equation describes the flux directed oppositely to direct diffusion, which originates due to concentration gradient and tends to balance the flux of thermal diffusion.

The condition of equilibrium of these oppositely directed salt concentration fluxes, usually dependent on ordinary and thermal diffusion, is specified by the formula

$$
\operatorname{grad} C=-\frac{D^{\prime} C(1-C)}{D} \operatorname{grad} T
$$

The salt content of pore water in bottom sediments will decrease until the formation of a stationary gradient, corresponding to the condition (2). Since "the marine sediments - seawater system" is open owing to permanent accumulation of sediments, such equilibrium is not formed, and a salt flux from bottom to top is constantly maintained.

Based on these concepts, the other phenomenon referred to above (increased salinity in the bottom soil upper layer as compared to bottom water salinity, a satisfactory explanation for which is still absent) can also be explained. As was noted above, the intensity of diffusion related only to concentration gradient is insignificant, especially at low temperatures [24]. At the same time, the process of thermal diffusion, as a result of which ion flux can be pronounced, terminates at the "bottom soil - water" interface since temperature gradient disappears in the bottom water layer: homothermy takes place at sea depths of 35-40 to $250 \mathrm{~m}$. Under these conditions, salts migrating from below are adsorbed and are reliably retained in the upper layer of bottom soils.

Thus, bottom sediments can freeze at a certain depth below the seabed since the salinity of pore water in bottom sediments decreases down the section.

This is confirmed by a simple calculation based on the published data $[19,23,24]$. The freezing temperature of seawater with a salinity of $35 \%$ is $-1.91^{\circ} \mathrm{C}$ [30]. According to the factual data, the natural water temperature in the bottom layer of the Arctic Ocean is $-1.8^{\circ} \mathrm{C}$; therefore, this water never freezes. The salinity of bottom sediments in the upper section is even higher; therefore, these sediments are also cooled, rather than frozen, to a certain depth. However, the salinity pronouncedly decreases with increasing depth, and temperature at a certain depth becomes sufficient for 
sediments to freeze. The combined variations in the bottom soil temperature (with grad $t=0.04^{\circ} / \mathrm{m} \mathrm{[19])} \mathrm{and} \mathrm{salinity}$ (according to [24]) plotted versus depth (Fig. 4) indicate that such conditions can originate at depths from 4.5 to $10-11 \mathrm{~m}$.

As sediments accumulate, the depth interval where the condition of pore water freezing is satisfied shifts upward synchronously with the upward motion of the seabed surface. The frozen sequence syngenetically grows in the same direction, from bottom to top. It is known that dewatering of accumulating sediments is a very slow process $[12,19]$. Therefore, slightly lithified and very wet bottom soils change into a layered ice-soil sequence.

As the frozen sequence grows upward, the temperature of the lower frozen layer increases in accordance with the temperature gradient. Therefore, this growth is finite and continues until the temperature of the growing sequence reaches $0^{\circ} \mathrm{C}$. Figure 4 indicates that the frozen sequence thickness can be not more than $40-50 \mathrm{~m}$ at the above temperature gradient and salinity since this sequence will thaw from below according to a change of negative temperature into positive ones. At other temperature gradient and salinity in a frozen condition thickness of deposits to $100 \mathrm{~m}$ can remain.

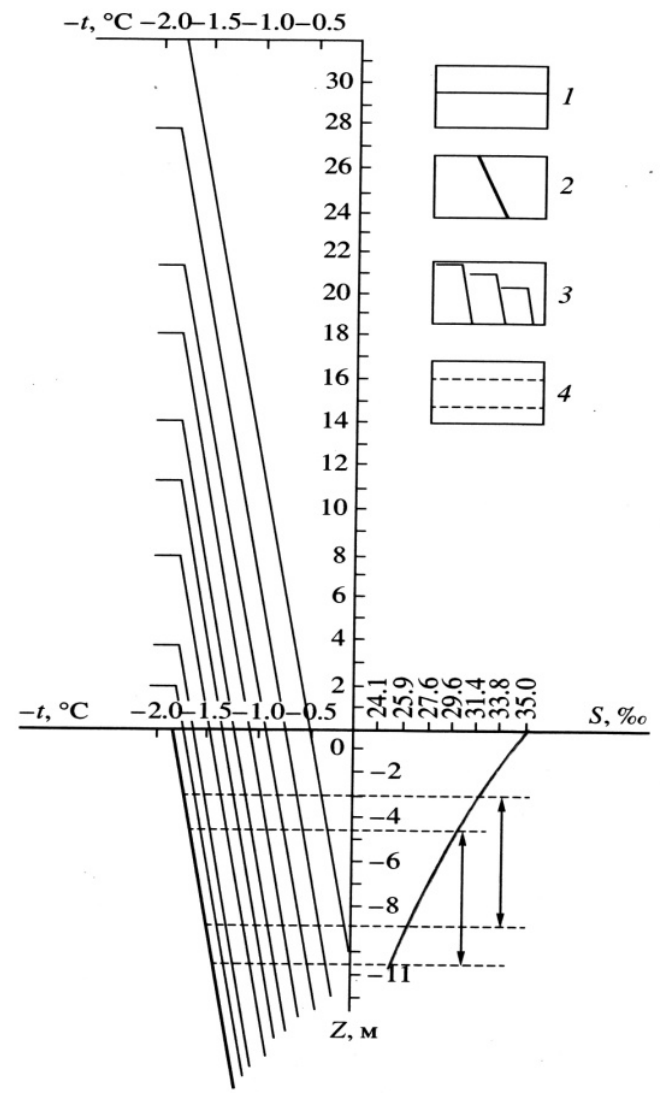

1 - seabed surface; 2 - recent temperature of bottom soils (vertical grad T $\left.=0,04^{\circ} / \mathrm{m}\right) ; 3-$ variation in bottom soil temperature with accumulation of sediments and upward motion of the seabed surface; 4 - depth interval with freezing bottom sediments. This interval also moves upward with accumulation of sediments

Figure 4. Joint graph of vertical variations $(\mathrm{Zm})$ in temperature $\left(\mathrm{T}^{\circ} \mathrm{C}\right)$ and salinity (S \%) of bottom sediments in the Arctic Shelf.
It is necessary to consider one more problem. Heat that is released during pore water freezing should propagate from the freezing front into bottom water layers. Nevertheless, the temperature of this water does not increase in this case. According to the observations, this temperature is always constant and the lowest at these depths because vertical density mixing constantly takes place in seawater. Since seawater density increases with increasing salinity and with decreasing temperature at close salinity values [30], bottom water moves upward and becomes warmer due to the income of phase transition heat and is replaced by colder water coming to the seabed surface. As a result, a stable density and temperature stratification rather rapidly recovers in water.

\subsection{Water Crystallization in Bottom Marine Sediments}

When submarine freezing is considered, two main questions arise: 1 - how pore water crystallizes and ice body is formed in bottom sediments; 2 - how salt ions migrate and are distributed during sludge water crystallization.

Freezing of bottom sediments can also be characterized as freezing of completely saturated soils and crystallization of highly mineralized water. In this case, according to V.I. Golubev's experiments [32], water distributed between mineral particles combines the surface of all particles into one system; therefore, appeared ice crystals rapidly grow and form basal ice. Since bottom soils freeze in a certain depth interval (see above), freezing front is replaced here by freezing zone, i.e., zone with negative temperatures. Ice crystals can originate simultaneously at many points of this zone, where the only necessary condition is satisfied: pore solution salinity should be so that the solution freezing temperature would correspond to this temperature. Growth of crystals is limited by adjacent crystals and soil particles. Before mineral particles, growth of ice crystals becomes slower and continues mostly due to a growth of bases along the surface of mineral particles in sedimentation layers, where dissolved gas and salt inclusions are adsorbed during growth of crystals. Therefore, originated ice streaks always inherit the form of even folded soil beds. In the process of growth of ice crystal, crystal faces force out ions and molecules of dissolved salts, as a result of which the zone of increased solution concentration is formed near crystals and increases in the course of time. Two processes proceed in this case [33, 34]. Growth of ice crystals slows down due to an increase in salt concentration in the fluid boundary layer. On the other hand, diffusion of salts from the boundary layer into the fluid volume becomes more intense due to an increased difference between salt concentration in the boundary layer and fluid volume. Some time after a growth onset, a dynamic equilibrium is established between the processes of increase in concentration in the solution boundary layer due to growth of crystals and decrease in concentration due to salt diffusion. Under constant thermodynamic conditions, crystals continue growing at a certain steady rate. As a result, the two-phase system is 
formed. This system includes fresh ice crystals and concentrated saline, which is uniformly distributed in bands between crystals [33, 35, 36]. At closing of ice crystals, saline is pressed out of these bands and is uniformly adsorbed on the surface of minerals in the ice-soil sequence. Ice remains fresh.

Salt distribution in frozen bottom sediments is inevitably closely related to facial conditions. Under the conditions of a deeper sea, when the finest (muddy) sediments with a high skeleton specific surface and, thereby, with a high surface energy are formed and freeze, salts pressed out during pore solution crystallization are completely adsorbed by the surface of mineral particles. Therefore, free pore water concentration always corresponds to a given freezing temperature, and ice crystals originate and grow without interruptions. Under the conditions of a shallower sea, when mostly sandy-silty sediments with usually low total surface energy are formed, uniform distribution of a saline over the surface of mineral particles is not observed. Pore solution concentration increases with increasing ice crystals, and unfrozen zones with a very high solution concentration are gradually formed since salts remain dissolved. Ice formation stops. In sediments that are newly accumulated in the upper section, ice is not formed until the process of thermal diffusion makes salinity equal to a necessary value. In such a case, water begins to freeze and ice starts forming. Ice crystals continue growing until the concentration of a pressed out solution reaches a critical value. An unfrozen zone with a very high solution concentration originates again. Cryopeg lenses in freezing bottom sediments are formed in such a way.

The considered dependence of salt ion distribution on facial conditions is also traced in certain publications. For example, when considering the processes of absorption at the «water - seabed» boundary, R. Horn [23] notes that absorption becomes more intense with decreasing grain size of absorbing particles. Therefore, deep-water fine-grained sediments are enriched in trace elements in contrast to coarser sediments accumulated in shallower water.

The shelf cryolithozone analysis shows that the structure features of ice-rich bottom sediments of the Barents-Kara Shelf, for example, at the Kara Strait or on Rusanovskaya Field [9, 14] complies with the initially subsea freezing mechanism described

\subsection{Analysis of Certain Frozen Sections with Massive Ice Beds within Marine Pleistocene Plains (Ancient Shelves)}

The Pleistocene marine plains of northern Eurasia (Western sector: the Western Siberia and North-East of European Russia) - ancient shelves, in the sections of which the processes that proceeded under submarine conditions were recorded - can be considered as an analog of the recent Arctic shelf. The study of the dislocated frozen sections with massive ice beds [8, 37-39], which are widespread within such plains, indicates that the above schematic formation of the shelf (submarine) cryolithozone is rather clearly defined in these sections. The structure of such a sequence indicates the appearance of the permafrost that is formed on the recent shelf.

The occurrence character and structure of similar ice beds (studied by the author in northern Western Siberia) reflect the sedimentation type of the entire sequence structure and indicate that these beds were formed under subaqueous conditions. As a rule, this section represents alternation of ice beds of thickness $10-15 \mathrm{~cm}$ and soil interlayers of thickness less than $1 \mathrm{~cm}$. Soil interlayers are not monolithic and also include ice microstreaks extended along bedding in parallel with one another. Layers are deformed and show a complicated pattern: parallel layers or layers interlacing in a complicated manner, sometimes horizontal, in other cases arched or of a complicated shape, located now closely to one another, now at a distance of several centimeters (Fig. 5 a). A similar ice-soil marine sequence with highly coordinated layers, observed even at a very complicated their configuration, could be formed only under submarine conditions during a syngenetic freezing of accumulating bottom sediments.

$$
\text { a }
$$

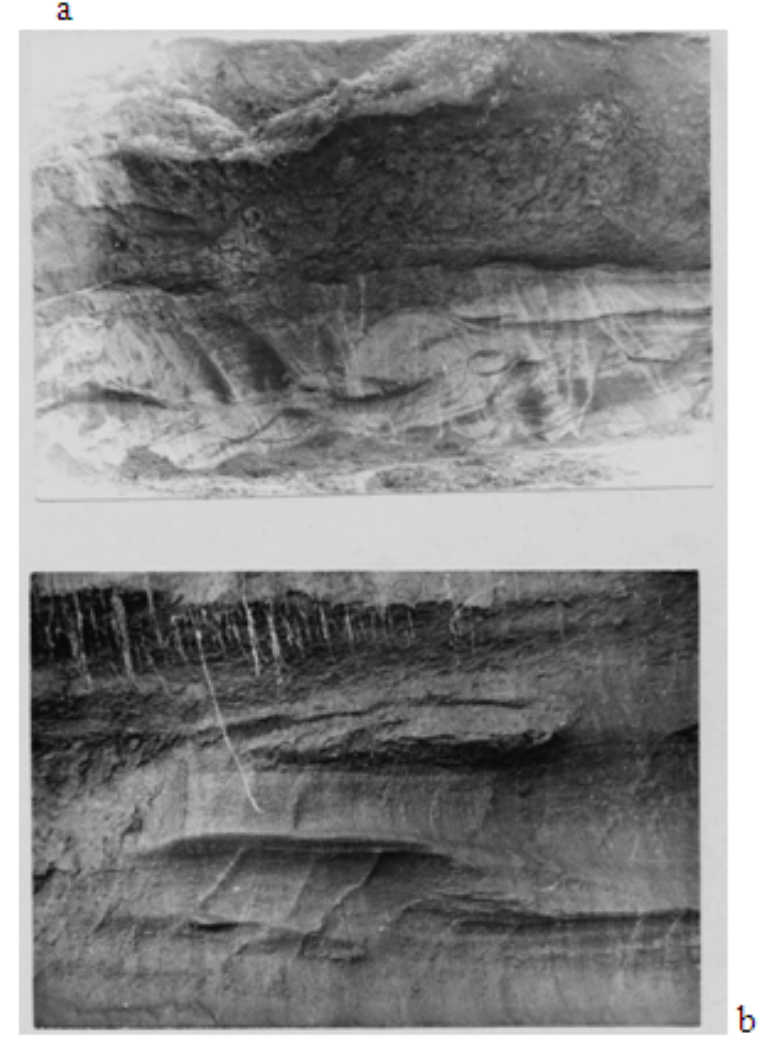

Figure 5. Dislocated massive ice bad of subsea genesis in the "Tadibeyakha" section (Western Gydan). A change in the cryogenic structure evidently follows a change in the lithology. a - clay section: uniform alternation of ice and soil laminas over the entire section indicates that ice continuously accumulates in a growing layer of frozen sediments. b - silty section: thicker and pronouncedly dislocated ice layers are separated by layers of massive soil, which indicates that ice accumulation was terminated due to increased concentration of pore solutions. Photo by N.A.Shpolyanskaya 
The idea of a possibility of submarine cryolithogenesis and related growth of dislocated ice beds was first put forward by Popov [39, 40] and was subsequently developed by Velikotskii [41], Danilov [42, 43], and Shpolyanskaya [8, $18,37,44]$. The idea is based on the fact that sedimentation is mostly accompanied by underwater landslide processes, as a result of which plicative dislocations originate in bottom sediments. Such dislocations originate in excess-moisture almost noncompacted sediments showing properties of floating and thixotropic soils. As a result of a change in the seabed slope during motion of such sediments, the entire sequence becomes shrunken, and not only regular but also reverse and drag, gentle and steep, folds of various dimensions are formed here. Plicative dislocations are traced over a distance of several tens and hundreds of meters along the strike and several hundred meters in vertical. In frozen sequences these dislocations are accompanied by a regular ice distribution along sedimentation folds, and massive ice beds are integrated with hosting dislocated sediments (fig.6). Such a relationship between dislocations and ice indicates that sediment deformation and ice formation are syngenetic [40].
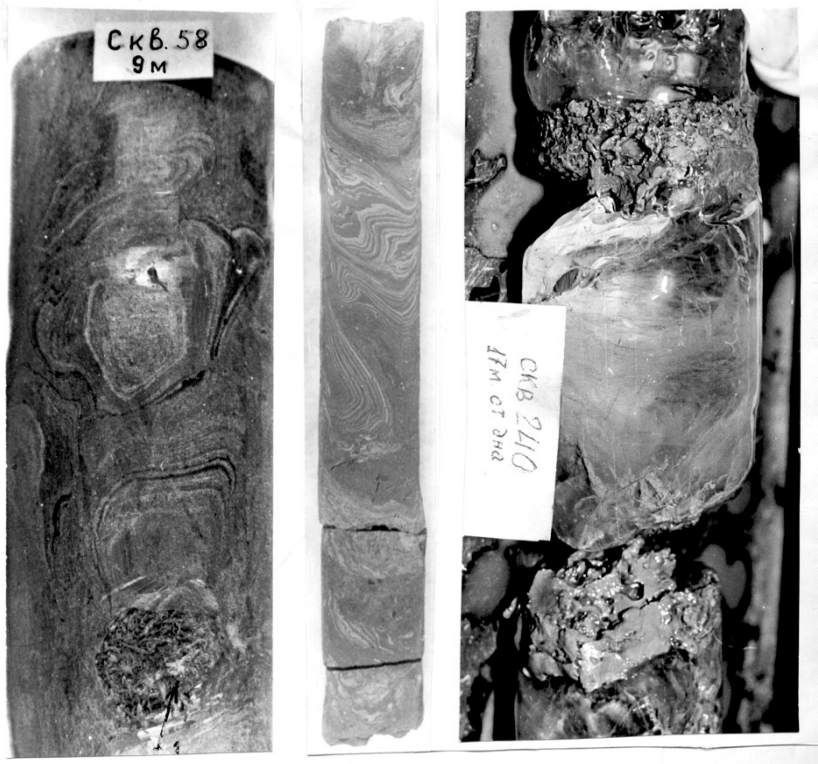

Figure 6. Ground ice in the Barents-Kara Shelf dislocated bottom sediments (Melnikov and Spesivtsev 1995, Bondarev et al. 2001).

At present, many researchers admit that massive ice beds were often formed immediately under submarine conditions $[12,27]$.

This mechanism is supported by facts. For example, in the Baydaratskaya Bay area in 42 drill sections [13] 12 cryopeg interbeds were found. There is only one reason for that breaks in the ice formation during silty sandy loam and silty sediments freezing.

The above mechanism of formation of the submarine cryolithtozone is clearly defined in the section of massive ice beds in central Yamal, studied by Streletskaya and Leibman [17]. The geological section from this work (Fig. 7) shows the sequence of marine Kazantsev sediments with a thick massive ice bed and cryopeg lenses. Ice is represented by alternation of ice and soil laminas of a sedimentation type. The sequence is generally salinized. However, Fig. 6 evidently demonstrates that cryopegs are not observed in the clay part of the section and are frequently encountered in the sand section. It should be noted that Streletskaya and Leibman [17] differently explain origination of cryopegs; however, dispute with these researchers is the subject-matter of an independent paper. Here we used the factual data, which, in our opinion, confirm the proposed mechanism of pore water crystallization in marine sediments.

Features of the proposed mechanism are also traced in other sections of the Pleistocene marine plains. Thus, a distinct change in the cryogenic structure following a change in lithology is observed in the ice bed section in the Tadibeyakha River basin on western Gydan Peninsula [37] (see Fig. 5). Ice and soil laminas regularly alternate in the clay section (Fig. 5a), which indicates that ice continuously accumulated in a growing frozen layer. In the sand-silt section (Fig. 5b), thicker and pronouncedly dislocated ice beds are separated by soil layers with a massive structure, which indicates that ice accumulation terminated due to increased pore solution concentrations.

Velikotskii [46] described presently forming massive ice beds within sand bars of the Pechora Sea on the Russkii Zavorot Peninsula. Massive ice bed in the presented section is underlain by cryopegs and grows from below at a contact with cryopegs. Marine salts are evidently pressed out by accumulating ice.

The data of Streletskaya and Leibman [17] demonstrates that ice and hosting sediment mineralization distribution along the section confirms the proposed mechanism of submarine cryolithogenesis. Thus, the total mineralization of pore solutions in clays near the ice bed is $20542 \mathrm{mg} / \mathrm{l}$, whereas the mineralization of ice interlayers in the same clay decreases to $189 \mathrm{mg} / \mathrm{l}$, and the mineralization of melt in the main part of massive ice bed is not higher than 78 $\mathrm{mg} / \mathrm{l}$. This results from salt pressing out of the zone between crystals during growth of ice crystals and from salt absorption by clay particles of rocks containing ice. The mineralization of solution in sand (cryopeg lenses) reaches $58507 \mathrm{mg} / \mathrm{l}$, whereas the mineralization of pore solution in sand outside these lenses is only $2407 \mathrm{mg} / \mathrm{l}$. It is clear that, in spite of a high salinity of clay, cryopegs are absent in these sediments. All salt ions are retained by the surface of soil mineral particles, whereas pore solutions in sand are desalinated because salt ions pressed out of pores by growing ice crystals accumulate in closed zones, forming cryopeg lenses, rather than are absorbed by sand particles.. 


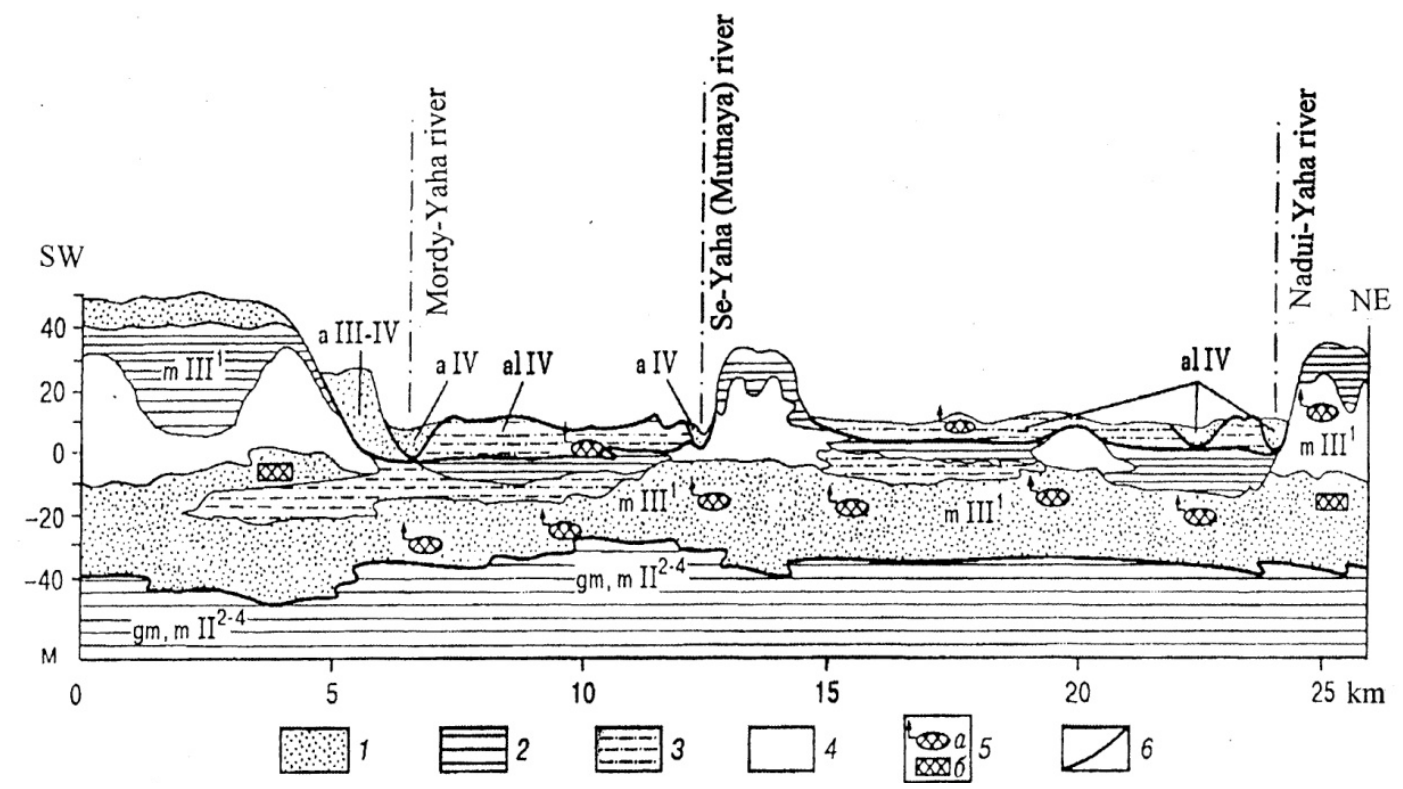

Figure 7. Schematic section of the Quaternary sediments of the central Yamal Peninsula with massive ice beds and cryopeg lenses. 1 - sand; 2 - clay; 3 alternation of sand, silty clay, and clay; 4 - massive ice bed; 5 - cryopeg lenses: a - established, $b$ - probable; 6 - boundary of the complex with massive ice bed (Streletskaya and Leibman [17])

A change in the salt ion composition along the section also does not contradict ice bed formation under submarine conditions. According to O.V. Shishkina [24], the chemistry of seawater in muddy sediments substantially changes. Sulfates are reduced in bottom sediments of northern and inner seas, as a rule, enriched in organic matter, as a result of which sulfate concentration in sludge water decreases and is followed by a replacement of $\mathrm{SO}_{4}^{-}$ion by $\mathrm{CO}_{3}$ and $\mathrm{HCO}_{3}$ ions. Sludge water is transformed into chloride-alkaline water of low sulfate content. Chloride-sodium-calcium water, the composition of which differs from the seawater composition, is formed during diffusion that causes exchange processes. Precisely this is traced in the ion structure of the considered section. The amount of $\mathrm{SO}_{4}{ }^{2-}$ ions sharply decreases in going from seawater to pore solutions of clay and sand. The amount of $\mathrm{HCO}_{3}{ }^{-}$increases in the same direction: from seawater to pore solutions. The role of $\mathrm{Na}^{+}$in the ion composition structure of pore solutions in clay increases as compared to such a role in seawater. This corresponds to the transformations of water ion structure in bottom sediments described by O.V. Shishkina. In this case the marine spectrum of ions is clearly defined in pore water of clays, ice interlayers, main beds of massive ice, and cryopegs.

One more situation should be considered. The presence of salt ions (which, seemingly, had to precipitate during ice formation) in cryopegs can also be explained. It is known [36] that joint presence of different ions in solution decreases salt precipitation temperature. For example, sodium sulfate precipitates at a temperature of $-7.6^{\circ} \mathrm{C}$ rather than at $-3.5^{\circ} \mathrm{C}$ as took place in pure solution of this salt. The only component precipitating soon after solution freezing, carbonates and hydrocarbonates $\left(\mathrm{HCO}_{3}\right)$, is absent in cryopegs. The presence of carbonates and hydrocarbonates in pore solutions of sediments containing ice is related to the technique for determining soil chemistry.

\subsection{Eastern Sector of the Arctic Shelf}

In contrast to the Shelf's Western Sector, the Arctic Shelf Eastern Sector cryolithozone is entirely represented by relict permafrost (Fig. 1 and fig. 8). Here an ancient icy complex of the Zyryan and Sartan Epochs flooded by a postglacial transgression can be noticed [6, 47-49]. Those are ice wedges which are wedge-shaped or column-shaped in section and form a polygonal system in plan. They form only in continental conditions on periodically flooded surfaces. Basic conditions for ice wedge formation are polygonal fracture system formation as a result of repeated soil surface thermal-contraction cracking and subsequent water penetration into the cracks.

On the Eastern Siberia plains, in contrast to the Western sector, ground ice is almost entirely represented by polygonal wedge ice which forms the so-called icy complex. Polygonal wedge ices are most widespread in the following areas - the Yana-Indigirka and Kolyma lowlands, the Central Yakut lowland, the New Siberian islands. Here, as distinct from the Western Arctic sector, the ice enclosing sediments are continental and belong to alluvial, alas, slope, coastal-marine, and lagoon types. Starting with the Pliocene, the Prymorskaya Lowland deposits are represented by lacustrine-alluvial, alluvial and lacustrine-bog deposits. The Olerskaya Suite deposits (Early Pleistocene) contain pseudomorphs after polygonal wedge ice $[50,51]$. On the Dmitri Laptev Strait coast and on Great Lyakhovsky island the strata with polygonal wedge ice age has the Middle Pleistocene age - 200000-180000 years ago, by $230 \mathrm{Th} / \mathrm{U}$ [52, 53]. The Late Pleistocene, starting from the Kazantsev time, 
is also represented exclusively by continental deposits [54]. Only in the Middle Pleistocene there was a little sea transgression which flooded a narrow coastal strip approximately from the Lena River mouth to the Chaun Bay [54] and formed a marine terrace aged 138000 years. [55].

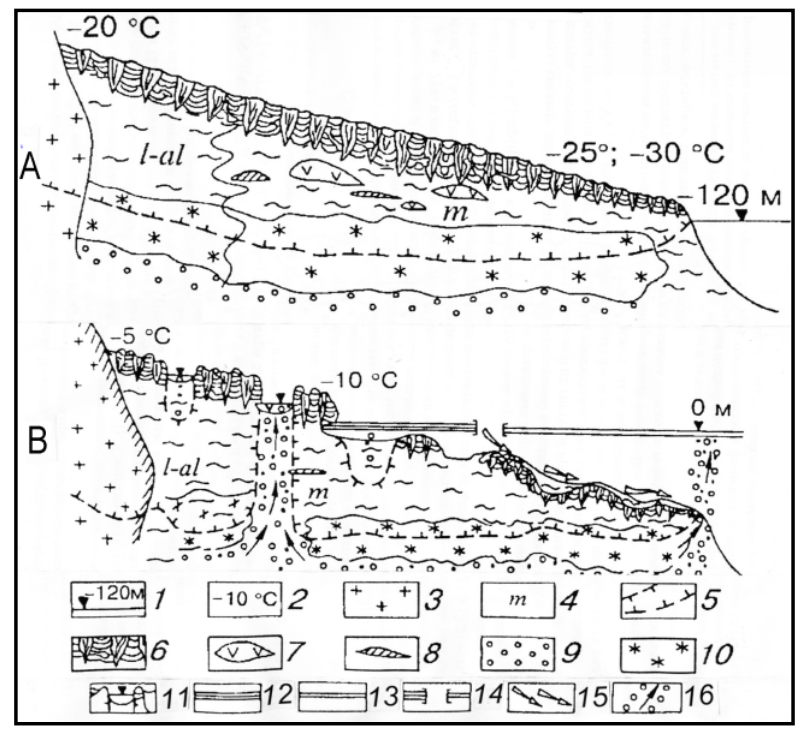

Figure 8. The Laptev Sea shelf structure [47]. A - 20000-18000 years ago, B - present time. 1 - sea level as related to modern; 2 - soil average annual temperature; 3 - bedrock; 4 - the Quaternary deposits genesis index; 5 permafrost boundary; 6 - ice complex; 7 - sheet ice; 8 - cryopeg lenses; 9 deposits containing free gas; 10 - deposits with gas hydrates; 11 -

thermokarst lake; 12 - fast ice; 13 - young ice; 14 - open lead; 15 - cold salt brine; 16 - greenhouse gases streams.

This points to the region's continental (as opposed to the Western Sector) development during the whole Pleistocene in the conditions of constantly severe climate and the absence of glacial cover.

\section{Conclusions}

1. The main conclusion follows from a performed analysis: the cryolithozone with massive ice beds can be formed under shelf submarine conditions and at a rather large depth.

2. Frozen dislocated sequences of an evidently submarine origin are observed within marine plains formed in northern Russia (on the Arctic Western Sector) during almost all stages of the Pleistocene. This means that these sequences were formed on ancient shelves during all epochs, both glacial and interglacial.

3. Therefore, we can assume that the submarine cryolithozone is also formed on the Arctic shelf.

4. At present, the main problem is to find differences between the cryolithozone, newly forming under submarine conditions, and the relic cryolithozone, which was formed under subaerial conditions and was subsequently flooded. Certain criteria of difference between the newly forming shelf cryolithozone and the relic zone can be proposed even now.

a) Newly forming (recent) permafrost can be encountered only at depths larger than $40 \mathrm{~m}$. Permafrost at smaller depths can be only relic.

b) Depending on the salinity of bottom sediments and the temperature gradient in these sediments, the recent permafrost thickness can vary from 50 to $80-100 \mathrm{~m}$, whereas the thickness of the relic permafrost can reach several hundred meters.

c) The recent permafrost temperature should be not lower than $-1.5 \div-1.6^{\circ} \mathrm{C}$, whereas the temperature of the relic permafrost can be even lower.

d) The cryogenic structure should reflect the syngenetic type of freezing: uniform alternation of ice and soil laminas and high conformity of layers even if their configuration is complicated. Since the relic permafrost is a subaerial formation, it should reflect the epigenetic type of structure: ice layers are rarefied with increasing depth.

e) The chemistry of sediments containing originating ice should reflect the marine type of salinization. Ice should be fresh.

5. The ice spatial patterns in relation to their genesis indicate the absence of ice sheets in the Pleistocene and Holocene on the Russian North plains, most likely, to the East of the Kanin Peninsula. A mountain-valley glaciation sometimes changing into reticulate glaciation occurred only in mountain areas.

6. The Arctic and Subarctic Eastern and Western sectors evolved differently in the Pleistocene, and transgressive-regressive regime was manifested them in different ways. During almost the whole Pleistocene (excluding the Sartan Epoch), the Western Sector plains formed under predominantly marine sedimentation conditions, and the Eastern Sector plains formed under continental, predominantly lacustrine-alluvial and lagoon sedimentation conditions. Only the regression of the last part of the late Pleistocene (the Sartan Epoch) and the Holocene transgression proceeded simultaneously.

7. The currently accepted synchronism "Glacial period - sea regression", "Interglacial period - sea transgression" is not detected. All the facts strengthen doubts in the glacioeustatic leading role in sea level variations and bring tectonic processes to the fore.

\section{Acknowledgements}

We are very grateful to experts of journal "Horizon Research Publishing" for their appropriate and constructive suggestions to improve this template. 


\section{REFERENCES}

[1] Pavlidis Yu. A., Ionin A.S., Shcherbakov F.A., N.N. Dunaev, and Nikiforov S.L. Arctic Shelf. The Late Quaternary History as the Basis for Predicting Evolution. GEOS, Moscow, 1998.

[2] Selivanov A.O. World Ocean Level Variations in the Pleistocene-Holocene and Development of Coasts, Water Problems Institute RAN, Moscow, 1986.

[3] Solovev V.A. Prediction of the Relic Subaqueous Frozen Zone (Using Eastern Arctic Seas as an Example), in Cryolithic Zone of the Arctic Shelf, Yakutsk, Russia, pp. 28 38. 1981,

[4] Solovev V.A. Barents Sea Shelf, in Geocryology of the USSR. European Part. Nedra, Moscow, 1988,

[5] Romanovskii, N.N., Kholodov, A.L., Gavrilov, A.V., Tumskoi, V.E., Hubberten, G.-V., and Kaccenc H. Thickness of Frozen Sequences in the Eastern Shelf of the Laptev Sea, Journal The Earth's Cryosphere, Vol. III, No. 2, pp. 22-32. 1999 ,

[6] Romanovskii, N.N., Tumskoi, V.E. Retrospective Approach to the Estimation of the Contemporary Extension and Structure of the Shelf Cryolithozone in East Arctic. Journal The Earth's Cryosphere, Vol. XV, No. 1, pp. 3-14, 2011.

[7] Shpolyanskaya, N.A. Pleistocene Paleogeography Of The Russian Arctic Based On The Analysis Of Underground Ice. Journal The Earth's Cryosphere, Vol. XVII, No. 2, pp. 12-25, 2013.

[8] Shpolyanskaya N.A. Features of the Arctic western Sector Permafrost in the Shelf-Land System. Journal Vestnik Moscow University, Ser. 5, Geography, No. 6, 58-66, 2010.

[9] Bondarev V.N., Loktev A.S., Drugach A.G., Potapkin Yu.V. Methods of Research and Determination of Subaqueous Permafrost. Proceedings of International Conference, Sedimentological Processes and Marine Ecosystems Evolution in Marine Periglacial, Apatity, Kolskiy nauchnyy tsentr, Volume 1, p. 15-19, 2001.

[10] Rekant P. Cherkashev G., Vanstein B., Krinitsky P. Submarine permafrost in the nearshore zone of the southwestern Kara Sea, Journal GeoMarine Letters. Vol. 25. DDI 10. 1007/s00367-004-0199-5. P. 183-189, 2005.

[11] Danilov I.D. Submarine Permafrost of the Arctic Shelf and Associated Lithomorphogenesis Cryogenic Processes. Journal Okeanologiya, Vol. 40, No. 5. p.756-764, 2000.

[12] Maslov, A.D., Cryogenic Diagenesis under the Conditions of Subaqueous Sedimentation, in Problems of Geocryology, Nauka, Moscow, pp. 41-55, 1988.

[13] Melnikov, V.P. and Spesivtsev, V.I., Engineering Geological and Geocryological Conditions of the Barents and Kara Sea Shelves, Nauka, Novosibirsk, 195 p. 1995.

[14] Rokos S.I., Dlugach A.G., Kostin D.A., Kulikov S.N., Loktev A.S. Permafrost of the Pechora and the Kara Sea shelves: Genesis, Composition, Distibution and Occurrence. Geotechnical investigation. Vserossiyskiy inzhenerno-analiticheskiy Journal, No 10, pp. 38-41, 2009.

[15] Romanovskii, N.N., Hubberten, G.-V., Kholodov, A.L., and Tipenko, G.S. State of Perennially Frozen Rocks on the Sea Shelves in the Eastern Sector of the Russian Arctic Regions,
Journal The Earth's Cryosphere, Vol. V, No. 2, pp. 3-10, 2001.

[16] Kassens H., Bauch H., Drachev S., Gierlichs A., Niessen F., Taldenkova E., Ruodoi A., Thiede I. and Wessels M. The Transdrift VIII Expedition to the Laptev Sea: The Shelf Drilling Compaign of "Laptev Sea System 2000". Proceedings of the Sixth Workshop on Russian-German Cooperation: Laptev Sea System. St. Petersburg, Program and Abstracts, № 8, pp. 39-40, 2000.

[17] Streletskaya, I.D. and Leibman, M.O., Cryogeochemical Interrelation between Massive Ice Beds, Cryopegs, and Hosting Sediments of the Central Yamal Peninsula, Journal The Earth's Cryosphere, Vol. VI, No. 3, pp.15-24, 2002.

[18] Shpolyanskaya, N. A. On the Possibility of Bottom Sediment Freezing in Arctic Seas, Journal Vestnik Moscow University, Ser. 5: Geography, No. 5, pp. 72-78. 1989.

[19] Zhigarev, L.A. Oceanic Cryolithozone. Moscow State University Press, Moscow,1997.

[20] Grigorev, N.F. Temperature Characterization of Bottom Sediments in the Kara Sea Coastal Zone, in Thermal Conditions of Soils and Rocks in Cold Regions, Yakutsk, pp. 101-111, 1982.

[21] Musina, A.A., Arctic Basin Hydrochemistry, Journal Procedings AANII, Vol. 218, pp. 5-64. 1960,

[22] Neizvestnov, Ya.V., Solovev, V.A., and Ginsburg, G.D.. Cryogenic Hydrothermal Problems is Studying the Arctic Ocean, in Engineering Geological Properties of the World Ocean Bottom Sediments, Leningrad, pp. 37-50, 1985.

[23] Horn, R. Marine Chemistry, Mir, Moscow, 1972.

[24] Shishkina, O.V. Geochemistry of Marine and Oceanic Sludge Water, Nauka, Moscow,1972.

[25] Shishkina, O.V. Sludge Water, in Ocean Chemistry, Vol. 2, Geochemistry of Bottom Sediments, Nauka, Moscow, pp. 252-290, 1979.

[26] Komarov, I.A. and Lukovkin, D.S. Technique of Qualitative Assessment of Salt Transfer Effect on Degradation of Subaqueous Perennially Frozen Rocks on the Barents Sea Shelf, Proceedings of the 2nd Conference of Russian Geocryologists, Moscow State Univ., Moscow, Vol. 2, pp. 154-163, 2001.Khimenkov, A.N. and Brushkov, A.V. Oceanic Cryolithogenesis, Nauka, Moscow, 2003.

[27] Pavlova, L.G. Salinity under the Ocean Periglacial Conditions in Arctic Seas, in Marine Periglacial and Glaciation of the Barents-Kara Shelf in the Pleistocene, Moscow, pp. 84-87. 1998.

[28] Fedorov, K.N. Many-Sided Coexistence of Saline and Fresh Water, Journal Priroda, No. 8, pp. 46-56, 1981.

[29] Zubov, N.N. Oceanological Tables, Gidrometeoizdat, Leningrad, 1957.

[30] De-Groot, S.R. and Mazur, P. Nonequilibrium Thermodynamics, Mir, Moscow, 1964.

[31] Golubev, V.N. Structural Ice Science. Congelation Ice Structure, Moscow State Univ. Press, Moscow, 2000.

[32] Golubev, V.N. Dependence of Ice Structure on Freezing Water Salinity, Proceedings of the 2nd International 
Conference on Cryolithology, Issue 4, Publishing house, Yakutsk, pp. 180-184, 1973.

[33] Golubev, V.N. and Sokratov, S.A. Differentiation of Solutes and Formation of Inclusions during Water Freezing, Proceedings of the International Conference Matter and Energy Conservation and Transformation in the Earth's Cryosphere, Pushchino, Russia, pp. 94-95, 2001.

[34] Golubev, V.N. Formation of Liquid Inclusions during Freezing of Mineralized Water, Journal The Earth's Cryosphere, Vol. IV, No. 3, pp. 51-58, 2002.

[35] Doronin, Yu.P. and Kheisin, D.E. Sea Ice, Gidrometeoizdat, Leningrad, 1975.

[36] Shpolyanskaya, N. A. Cryogenic Structure of Dislocated Sequences with Massive Ice Beds as an Indication of Their Genesis (Northern Western Siberia), Journal The Earth's Cryosphere, Vol. IV, No. 4, pp. 61-70, 1999.

[37] Shpolyanskaya, N. A. and Streletskaya, I.D. Massive Ice Beds in Marine Pleistocene Sediments in the Russian Subarctic Regions, Journal Izvestia PAN, Ser. Geographic., No. 4, pp. 93-102, 2003

[38] Shpolyanskaya, N. A. and Streletskaya, I.D. Genetic Types of Massive Ice Beds and Specific Features of Their Distribution in the Russian Subarctic Regions, Journal The Earth's Cryosphere, Vol. VIII, No 4, pp. 56-71, 2004.

[39] Popov, A.I. On Dislocations and Lithogenesis in the Pleistocene of Northern Eurasia, Journal Vestnik Moscow University, Ser. 5: Geography, No. 3, pp. 3-9, 1984.

[40] Popov, A.I. On Submarine Type of Cryogenic Diagenesis, Journal Engineer Geology, No.6, pp. 49-55, 1991

[41] Velikotskii, M.A., Dislocations and Massive Ice Beds in the Quaternary Sediments on the Yamal Peninsula, in Cryogenic Processes, Moscow State University Press, Moscow, pp. 48-60, 1987.

[42] Danilov, I.D. Cryogenic-Diagenetic Formations in the Arctic Sea Sediments, Journal Lithol. Polezn. Iskop., No. 3, pp. 132-136, 1989

[43] Danilov, I.D., Buldovich, S.N., and Lukovkin, D.S. Model of the Thermal Exchange Dynamics in the Kara Shelf and Paleoshelf Rocks in the Late Pleistocene-Holocene and Submarine Cryolithogenesis, Journal The Earth's Cryosphere, Vol. III, No. 4, pp. 54-60, 1999.

[44] Shpolyanskaya, N. A. Submarine Cryolithozone in the Russian Arctic Regions and Its Evolution in the
Pleistocene-Holocene, Proceedings of the 1st Conference of Russian Geocryologists, book 3, Moscow State University Press, Moscow, pp. 404-413, 1996.

[45] Velikotskii, M.A. On Massive Ice Beds within Sand Bars of the Pechora Barrier Beach, in Problems of General and Applied Geoenvironmental Sciences in Northern Regions, Moscow State University Press, Moscow, pp. 148-154, 2001.

[46] Romanovskiy N.N., Gavrilov A.V., Kholodov A.L., Khubberten Kh-V., Kassens Kh. Reconstruction of Paleogeographic Conditions of Laptev Sea Shelf for Late Pleistocene-Holocene Glacioeustatic Cycle. Journal The Earth's Cryosphere, Vol. I , No 2, pp. 42-49, 1997. Romanovskii, N.N., Hubberten, G.-V., Kholodov, A.L., and Tipenko, G.S., State of Perennially Frozen Rocks on the Sea Shelves in the Eastern Sector of the Russian Arctic Regions, Journal The Earth's Cryosphere, Vol. V, No. 2, pp. 3-10, 2001.

[47] Schirrmeister L.,Kunitsky V.V., Grosse G. et al. The Yedoma Suite of the Northeastern Siberian Shelf Region Characteristics and Concept of Formatijn, Proceedings of of the Ninth International Conference on Permafrost, Fairbanks, Alaska, pp. 78-80, 2008.

[48] Arkhangelov A.A., Konishchev V.N., Rozenbaum G.E. Primorsko-Novosibirsky Region, in Regional cryolithology, Moscow State University Press, Moscow, p. 128-151, 1989.

[49] Nikolskiy P.A., Basilyan A.E. Cape Svyatoy Nos, Proceedings of III Vserosijsky Conference on studying Quarternary Period, Section of Quaternary sediments of the North of Yano-Indigirkaya Lowland. Smolensk, Russia, p. 186-188, 2002.

[50] Schirrmeister L., Oezen D, Gey M.A. 230Th/U dating of frozen peat, Bol'shoy Lyakhovsky Island (North Siberia), Journal Quarternary research, Vol. 57. P 253-258, 2002.

[51] Tumskoy V.E.. Peculaiarities of cryolithogenesis in northern Yakutia (Middle Neopleistocene to Holocene), Journal Earth's Cryosphere, Vol. XVI, N 1, pp. 12-21, 2012.

[52] Alekseev M. N., Arkhangelov A.A., Grinenko O.V., Kim B.I., Patyk-Kara N.G., Plakht I.G., Reynin I.V. The Laptev and the East Siberian Seas shelf in the Mesozoic and the Cenozoic. Atlas of Palogeographic Maps, Robertson GRUP-GIN ANSSSR, Vol. 2 (edit. M.N. Alekseev), 1992.

[53] Bolshiyanov D.Yu., Grigorev M.N., Shnayder V., Makarov A.S., Gusev E.A. Sea Level Variations and Ice Complex Formation on the Laptev Sea coast, in System of the Laptev Sea and the adjacent Arctic seas, Moscow State University Press, Moscow, p. 349-356, 2009. 